\title{
EDUCATING THE TECHNOLOGY OFFICER OF THE FUTURE: A NEEDS ANALYSIS
}

\author{
Christopher Wydra, California University of Pennsylvania, wydra@calu.edu \\ Frank Hartle III, Robert Morris University, hartle@rmu.edu
}

\begin{abstract}
This quantitative, case study explores the importance of IT, CIS, Computer Science, and Communications as interdisciplinary degree programs with criminal justice curriculum. The researchers examined the future technology skills needed by police agencies, the current recruiting trends by police departments and compared these needs with current four year, accredited criminal justice programs. The researchers then examined the perceptions of criminal justice major students and their assessment of the importance and impact of technology in law enforcement today and in the near future. The data demonstrates how criminal justice students' perceptions allude to the importance and relevancy of technology in law enforcement and how CJ programs are not adequately preparing them for future policing needs. In addition, police agencies are not effectively recruiting technology officers to meet current and future technological needs for law enforcement.
\end{abstract}

Keywords: Technology Officer, Datafication, Criminal Justice

\section{INTRODUCTION}

Policing is being transformed by technology and, as such, is changing rapidly. Traditional policing, investigations and administration processes are transforming as new technology is developed and adopted. As society embraces new ways to do business, communicate and safeguard intellectual property, policing is being compelled to adopt and adapt. As society moves towards a more connected and digital way of life, policing will have to adapt. The Internet of Things (IoT), cyber-crime, the proliferation of mobile smart devices and the increasingly connected surveillance systems used in business and by the government has forced policing into the $21^{\text {st }}$ century. The adoption of these technologies for use as a tool for policing is also increasing [4]. The use of social media, predictive analysis, wearable cameras and robot and drone use have begun to permeate police agencies. So, too, has the dataification of evidence. Evidence that was primarily physical has become increasingly digitized such as firearms information, DNA, and photographs. The use of facial recognition, DNA and trace firearm databases are only a small example of how policing is being digitized. The addition of police reports both current and historical, vehicle and crime data bases as well as public records have all been digitized. Together with newer forms, evidence from digital sources such as IoT, networked policing, smart devices and computers, one can see the size and scope of technological policing [7]. In a 2015 report of future police needs from the National Institute of Justice [16], state:

In the future, law enforcement will have to function in an environment in which advances in technology and the evolution of society may significantly affect both the nature of laws and of their enforcement. To achieve their missions, law enforcement organizations will need to utilize advanced technologies. The balance between law enforcement and those planning or committing crimes or endangering public safety and security will also be shaped by new technology, with the advantage in some cases going to law enforcement and in some cases to the perpetrators.

Traditionally law enforcement has been slow to adopt new technology. This is not due to any willingness on the part of the police [19]. Two primary reasons police are slow to adopt technology is cost and training [16]. History shows us that major advancements in police technology occurred when federal funding became available and/or when it was necessary to combat new crime [19]. The initial cost of combating the technological nuances of crime have and will continue to be borne by the government, however, the sophistication of newer crime has required more public and private cooperation [9]. The cost of police technology and who will bear that cost is not in question, nor is the continued proliferation of multiple forms of technology, the datafication of evidence and the persistent maturation of cyber-criminals. The one area of technology policing that is being ignored by both police professional and academia alike is the training and recruitment of the future technology police officers. 


\section{Police Recruiting}

Police recruiting traditionally focuses on agency need. It is no secret that police departments have increasingly focused on minority and female recruiting to meet the needs of our diverse community $[1,12]$. In addition, police departments have begun to require either a college degree or some minimum amount of college credits [10]. Departments believe that recruiting officers with college experience will better prepare officers to deal with the complex writing requirements and decision making and to gain recruits with wider world perspective [6]. Interestingly, the concentration and/or area of study of the college credits do not have to be related to law enforcement to meet the many credit standards nationally set by police hiring agencies. Criminal justice and criminology majors have reported that $\mathrm{CJ}$ degrees equipped them for employment interviews and better prepared them for their law enforcement career. [18, 14]. Most people who go to college, with the idea of entering law enforcement, major in criminal justice or a related major. Few would argue the need for a more diverse and educated police force, however, police agencies are failing to recognize the need to recruit officers with technical skills. As stated above, the technical evolution of police work coupled with the dataification of evidence is creating a need for technology officers who can investigate complex technical cyber-crimes, forensically examine digital evidence, maintain and deploy field robots and drones, operate and maintain predictive policing hardware and software, maintain and operate wearable cameras and devices, utilize social media tools, code apps, and maintain the various disparate data sources and data bases, to name a few. Police organizations are not proactively recruiting for these specially trained technology officers [16].

\section{Criminal Justice Education}

Criminal justice (CJ) programs have evolved for the last 90 years to primarily focus in four areas; vocational, professional, theoretical or multi-disciplined [2]. Most criminal justice programs offer theoretical or vocational orientations [18]. The theoretical approach focuses on the causes and approaches to the crime problem, victimology and/or restorative justice, while the vocational approach focuses on the processes of police work. While the literature suggest that a multi-discipline approach is best for producing better prepared criminal justice graduates, few CJ programs effectively incorporate multiple orientations. [2,4]. Moreover, even fewer CJ programs focus on the technological aspect of CJ. Many CJ programs are beginning to add classes or concentrations in cyber-crime and/or data forensics however few employ the multi-disciplinary approach. Birzer, and Palmiotto, [2] argue that CJ programs should be grounded in both theory and practice, and that theory should be shown to intricately relate and drive fundamental practice. Technology education and training are fundamental to police agencies keeping up with crime trends, officer safety and police community relations [16]. Furthermore, CJ programs are not cognizant of this trend and have not adapted their programs to meet future policing needs. As an example, the National Institute of Justice highlighted the following example of future police needs in their report titled, Visions of Law Enforcement Technology in the Period 2024-2034 [16]:

Table 1

\begin{tabular}{|l|l|}
\hline Intelligent agents & $\begin{array}{l}\text { Approaches to identify and recruit best candidates for } \\
\text { new network-centric environment }\end{array}$ \\
\hline Collaboration applications, tools, systems & $\begin{array}{l}\text { Change in training toward new network-centric } \\
\text { environment }\end{array}$ \\
\hline $\begin{array}{l}\text { Strategy, doctrine, and procedures for using network- } \\
\text { centric technologies }\end{array}$ & $\begin{array}{l}\text { Skillset/culture shift/incentives toward productive } \\
\text { collaboration to take advantage of information-sharing } \\
\text { capabilities }\end{array}$ \\
\hline Leadership and ethics for the network-centric era & Augmented reality technologies. \\
\hline Social media and messaging & Biometrics development \\
\hline Sensors development & $\begin{array}{l}\text { Analytics development (to monitor the sensors), } \\
\text { including "Total Information Awareness"- type } \\
\text { applications }\end{array}$ \\
\hline $\begin{array}{l}\text { Increased bandwidth for networking } \\
\text { "Smart, tactical, mobile, semi-autonomous" camera } \\
\text { systems to document interactions- needs include } \\
\text { consideration of when they should be used, cultural } \\
\text { shifts and training, identification of best uses }\end{array}$ & $\begin{array}{l}\text { Change in law enforcement personnel mix toward } \\
\text { those with technology expertise (along with strategies } \\
\text { to help bring about the personnel mix changes) }\end{array}$ \\
\hline
\end{tabular}




\section{Current Criminal Justice Curriculum, Education and Training}

Many law enforcement agencies today are requiring, or prefer, new hires to a college education upon being hired [10]. Research has shown that college educated police officers are more effective at problem solving, communication, and less prone to use excessive force [13]. Law enforcement administrators realize that a collegeeducated officer can be an asset to their agency. Many law enforcement agencies also provide incentives, such as financial assistance from the agency, for their officers to obtain a college education or continue their college education [12]. Many college degree curricula, whether on-ground, hybrid (blended on-ground and online), or fully online programs offer a variety of criminal justice degrees with varying criminal justice concentrations. Although, many of these criminal justice programs that offer degrees focus on criminal justice related concentrations. Very few programs throughout the United States offer criminal justice programs that are interdisciplinary and integrated with Information Technology (IT), Computer Information Systems (CIS), Computer Science, or Communications.

In an effort to understand $\mathrm{CJ}$ and criminology offerings and to explore if current $\mathrm{CJ}$ and criminology programs are focused on future police needs, the authors focused on one Northeast state's CJ and criminology curricula. The authors examined 24, four- year CJ or Criminology programs in the state of Pennsylvania and four well- known national programs (Table 2 and 3). This study was limited to Pennsylvania; however, four well- known, national programs were included for comparison. All the CJ programs were either a B.S or B.A. and all were from accredited, non-profit colleges or universities. None of the 28 programs were identical, as each varied in curriculum and graduation requirements. The majority (25) of the $\mathrm{CJ} / \mathrm{Criminology}$ programs offered a mixture of theoretical and vocational courses. However, the majority of the programs leaned heavily to the theoretical and social side of criminal justice.

Table 2

\begin{tabular}{|l|l|l|}
\hline \multicolumn{3}{|c|}{ Criminal Justice / Criminology Programs - Pennsylvania } \\
\hline Regis University : B.S. Criminology & Robert Morris University: B.A. CJ & DeSales University: B.A. CJ \\
\hline Edinboro University : B.A. CJ & $\begin{array}{l}\text { Slipper Rock University: B.A. CJ } \\
\text { and Criminology }\end{array}$ & Seaton Hill University: B.A. CJ \\
\hline La Roche College: B.A. CJ & Temple University: B.A. CJ & Widener University: B.A. CJ \\
\hline Mercyhurst University: B.A. CJ & Thiel College: B.A. CJ & York College: B.S. CJ \\
\hline Penn State University: B.S. CJ & Villanova B.A. Criminology & $\begin{array}{l}\text { University of Pennsylvania: B.S. } \\
\text { Criminology }\end{array}$ \\
\hline Point Park University: B.S. CJ & Waynesburg University: B.A. CJ & $\begin{array}{l}\text { Indiana University of } \\
\text { Pennsylvania: B.A. Criminology }\end{array}$ \\
\hline St. Francis University: B.S. CJ & $\begin{array}{l}\text { California University of } \\
\text { Pennsylvania: B.S. CJ }\end{array}$ & Scranton University: B.S. CJ \\
\hline Clarion University: B.S. CJ & Gannon University: B.A. CJ & $\begin{array}{l}\text { Drexel University: B.S. } \\
\text { Criminology }\end{array}$ \\
\hline
\end{tabular}

Table 3

\begin{tabular}{|l|l|}
\hline \multicolumn{2}{|c|}{ Criminal Justice / Criminology Programs Nationally } \\
\hline John Jay College: Computer Information in CJ & Arizona State University: B.S. CJ and Criminology \\
\hline University of California Irvine: B.A. Criminology & University of Florida: B.A. Criminology \\
\hline
\end{tabular}

Only three CJ programs came close to offering curriculum to meet some of the requirements of the above mentioned 2015 NIJ report (Table 4). Out of these three programs only one was best suited to produce technology police officers.

Table 4 Criminal Justice / Criminology Programs for the Technology Officer

\begin{tabular}{|l|l|l|}
\hline $\begin{array}{l}\text { Drexel University: B.S. } \\
\text { Criminology (Informatics } \\
\text { Concentration) }\end{array}$ & $\begin{array}{l}\text { John Jay College: Computer } \\
\text { Information in CJ }\end{array}$ & $\begin{array}{l}\text { DeSales University: B.A. CJ } \\
\text { (Digital Forensics ) }\end{array}$ \\
\hline
\end{tabular}


Drexel University's Criminology Informatics concentration offered the most well- rounded curriculum incorporating a theoretical, vocational and technical multidiscipline approach as recommended in the literature. While the program doesn't meet all the NIJ report's future needs, it covers a wide swath of them. The John Jay College program is a good start, but lacks the multidisciplinary requirement as it offers little in the way of police theory and practice. DeSales University's Digital Forensics program is a good mixture of theory and practice but is limited to one aspect of digital crime. This program may need more offerings with wider technological focuses as outlined in Silberglitt [16], to meet the needs of the technology officer.

Many other programs listed above offer minors and concentrations in digital forensics or have information systems, IT or computer science majors in other departments. Without much effort, many of the schools above could quickly create CJ technology programs to meet the needs outlined above.

\section{RESEARCH METHODOLOGY}

A case study analysis was used for this study to determine criminal justice students' perceptions of the impact of technology in policing. The case study used a quantitative method that examined criminal justice majors' knowledge, skill, and expertise with technology and IT devices. The study also explored if students believed that forms of technology and IT devices play a role in policing. A QuestionPro survey tool was used to collect data for this study. The survey participants are criminal justice majors from universities located in Southwestern Pennsylvania. This research topic was explored due to the limited research on student's perceptions of technology and law enforcement and criminal justice degrees that are not integrated with IT, CIS, Computer Science, and Communication disciplines. A purposeful convenience sampling was used to reach a core group of criminal justice majors at universities in Southwestern Pennsylvania that take criminal justice courses in criminal justice programs. A case study method for this study was chosen as it examined why criminal justice students believe they are skilled with technology and how technology plays a role in law enforcement and was configured to use a quantitative survey.

Case study research can be related to quantitative research and is a methodological means of defining a study [20, 3 , 17]. Creswell [3] defines case study research as "research, which involves the study of a case within a real-life, contemporary context or setting." A case study may be a small group, a community, or a relationship within parameters such as place or specific time. A case study researcher studies current, real-life situations in progress so the case study can gather information not lost by time [3]. Creswell's definition of case study as a methodology aligns with the design of this study as a quantitative approach. A quantitative approach is a more effective way to reach a group of geographically dispersed criminal justice majors from universities in Southwestern Pennsylvania. According to Yin [20], a case study is empirical research using multiple sources for a methodological model that suggests using a six-step technique to conduct, organize, and develop a case study.

The research participants were directed to participate in the study by means of an email requesting participation through QuestionPro, an online survey instrument. Students answered Likert scale survey questions that assisted with the data collection. QuestionPro streamlined the survey procedure by collecting data from survey participants, storing the data, and providing survey results in real time. This method was the basis of the questionnaire designed to obtain opinions, attitudes, and characteristics of criminal justice majors. Nardi [11], states, "self-administered questionnaires are best designed for:

- Measuring variables with numerous values or response categories that are too much to read to respondents in an interview or on the telephone,

- Investigating attitudes and opinions that is not usually observable,

- Describing characteristics of a large population,

- Studying behaviors that may be more stigmatizing or difficult for people to tell someone else faceto-face."

\section{Student's Perceptions of the Future of Law Enforcement}

This study gathered and analyzed quantitative data using the QuestionPro survey tool. The survey participants were criminal justice major students who attend universities that offer undergraduate and graduate degrees in criminal 
justice related fields. The student participants remained anonymous and completed the survey through an online survey link. One hundred twenty-two surveys were distributed and 117 students completed the survey with a $95 \%$ completion rate. Of the 117 student participants, $55.5 \%$ were male students and $44.5 \%$ were female students and $95.69 \%$ of all survey participants are considering a career in the criminal justice field. The survey consisted of 28 survey questions in Likert scale format. The survey focused on student's perceptions of their skills and knowledge of technology and the impact of technology in the law enforcement field. Students were asked, in their opinion, how experienced, skillful, and knowledgeable they are with computers, mobile devices, social media, wireless devices, databases, and computer analytics. They were also asked, in their opinion, how law enforcement uses computers, mobile devices, social media, wireless devices, databases, crime mapping, robots, and drones.

\section{RESULTS}

Data was collected from survey participants and analyzed with the online QuestionPro survey instrument. Students' perceptions revealed that they believe they have experience, knowledge, and skills with various forms of technology. Students also believe that technology is used and will be used in the law enforcement field; $92.3 \%$ of participants believe technology will play a very important role in the future of law enforcement. The survey asked specific question relating to various technologies used or will be used in the law enforcement field. For example, student participants were asked if video technology captures almost all crime, and $62.38 \%$ of participants responded that they strongly agreed, and agreed that video technology captured almost all crime. Below are tables depicting the data analysis from data collected by criminal justice students' perceptions. Table 5 delineates the technology used by survey participants and the classification of technology usage including: always use, sometimes use, rarely use, or never use and very experienced, experienced, little experience, or no experience. Students were asked how often they used social media and technology and how much experience they have using predictive software, databases, wireless networks, wireless communication devices, wireless cameras, robots and drones, and developing apps.

Table 5. Perception of Technology Used by Student

\begin{tabular}{|c|c|}
\hline Technology Used by Student & Classification of Usage \\
\hline Social media user & $\begin{array}{ll} & 49.5 \% \text { - always use } \\
\cdot & 44.4 \% \text { - sometimes use }\end{array}$ \\
\hline Technology user & $\begin{array}{l}\text { - } \quad 68.6 \% \text { - experienced } \\
\text { - } 34 / 1 \% \text { - very experienced }\end{array}$ \\
\hline Experience using predictive software & $\begin{array}{ll} & 51.2 \% \text { - little experience } \\
\text { - } & 3.4 \% \text { - very experienced }\end{array}$ \\
\hline Experience using databases & $\begin{array}{l}\text { - } \quad 45.9 \% \text { - experienced } \\
\text { - } \quad 6.9 \% \text { - very experienced } \\
\text { - } \quad 43.9 \% \text { - little experience }\end{array}$ \\
\hline Experience using wireless networks & $\begin{array}{ll} & 52.5 \% \text { - experienced } \\
- & 34.4 \% \text { - very experienced }\end{array}$ \\
\hline Experience using wireless communication devices & $\begin{array}{l}\quad 50.4 \% \text { - very experienced } \\
\text { - } \quad 39.3 \% \text { - experienced }\end{array}$ \\
\hline Experience using wireless cameras & $\begin{array}{ll} & 42.7 \% \text { - experienced } \\
\text { - } & 26.5 \% \text { - very experienced } \\
\text { - } & 23.9 \% \text { - little experience }\end{array}$ \\
\hline Experience using robots and drones & $\begin{array}{ll}- & 65.8 \% \text { - no experience } \\
- & 28.2 \% \text { - little experience } \\
\end{array}$ \\
\hline Experience developing apps & $\begin{array}{ll} & 73.5 \% \text { - no experience } \\
- & 18.8 \% \text { - little experience } \\
\end{array}$ \\
\hline
\end{tabular}

Table 5 illustrates that the majority of students have the perception that they use social media and technology often and the majority are very experienced or experienced at using wireless networks, wireless communication devices, and wireless cameras. Although most students believe they are experienced with some technology, they have little or no experience using predictive software, robots and drones and developing apps.

Criminal justice students were also asked about their perceptions of technology in the future of policing in the survey. Table 6 below reflects student's perceptions that they believe technology will play a sizeable roll in the future of the criminal justice field. The majority of student participants agree that technology will impact police 
actions, investigations, and accountability. Table 6 outlines how likely technology will be used in the future of policing or if they agree that certain technology will be used in the future of policing.

Table 6. Student's Perceptions of Technology in the Future of Policing

\begin{tabular}{|c|c|}
\hline Student's Perceptions of Tech in Future Policing & Classification of Perception \\
\hline $\begin{array}{l}\text { Law enforcement usage of large predictive software and } \\
\text { databases }\end{array}$ & $\begin{array}{ll}\text { - } & 75.2 \% \text { - very likely } \\
\text { - } & 22.2 \% \text { - likely }\end{array}$ \\
\hline Law enforcement will utilize wireless cameras & $\begin{array}{l}\text { - } \quad 79.1 \% \text { - definitely } \\
\text { - } 20 \% \text { - probably } \\
\end{array}$ \\
\hline Law enforcement will utilize robots and drones & $\begin{array}{ll} & 38.7 \% \text { - probably } \\
\text { - } & 29.3 \% \text { - definitely } \\
\text { - } & 26.7 \% \text { - maybe } \\
\end{array}$ \\
\hline $\begin{array}{l}\text { Law enforcement will use social media for } \\
\text { communication and investigation }\end{array}$ & $\begin{array}{l}72.6 \% \text { - definitely } \\
\text { - } \quad 19.6 \% \text { - probably }\end{array}$ \\
\hline Law enforcement will need cyber forensic investigators & - $83.7 \%$ - definitely \\
\hline Law enforcement will need people to develop apps & $\begin{array}{l}\text { - } \quad 53.8 \% \text { - definitely } \\
\text { - } \quad 34.1 \% \text { - probably }\end{array}$ \\
\hline Technology plays a vital role in police work & $\begin{array}{l}\text { - } \quad 66.6 \% \text { - strongly agree } \\
\text { - } \quad 31.6 \% \text { - agree }\end{array}$ \\
\hline Technology required to effectively investigate crime & $\begin{array}{ll} & 54.7 \% \text { - strongly agree } \\
\text { - } & 38.4 \% \text { - agree } \\
\end{array}$ \\
\hline Criminals use some sort of technology to commit crime & $\begin{array}{ll} & 52.9 \% \text { - agree } \\
\text { - } & 43.9 \% \text { - strongly agree }\end{array}$ \\
\hline $\begin{array}{l}\text { Technology holds police officers accountable for their } \\
\text { actions }\end{array}$ & $\begin{array}{l}\text { - } 49.1 \% \text { - strongly agree } \\
\text { - } 41.3 \% \text { - agree }\end{array}$ \\
\hline Police officers should be required to wear body cameras & $\begin{array}{l}\text { - } \quad 45.3 \% \text { - strongly agree } \\
\text { - } 39.2 \% \text { - agree }\end{array}$ \\
\hline $\begin{array}{l}\text { Digital evidence are key pieces of evidence in criminal } \\
\text { prosecution }\end{array}$ & $\begin{array}{l}\text { - } \quad 67.5 \% \text { - strongly agree } \\
\text { - } \quad 31.6 \% \text { - agree }\end{array}$ \\
\hline
\end{tabular}

Table 6 illustrates that the majority of students have the perception that technology is used or will be used in policing and that technology is and will play a vital role in policing. The majority of students believe that law enforcement will definitely or are very likely use predictive software, wireless cameras, social media for communication and investigations, and will use robots and drones for policing. A large portion of the student participants also believe that law enforcement will need cyber forensic investigators, people to develop apps, technology will be needed to effectively investigate crime, digital evidence are key pieces of evidence, police officers should wear body cameras, and technology hold police officers accountable for their actions.

Tables 5 and 6 above describe how students believe technology will play a vital role in law enforcement and how experienced and skilled they are with technology.

\section{Summary of Student Perceptions}

The analysis of the data collected from criminal justice survey participants reveal that students believe technology does or will play a vital role in different aspects of policing. The analyzed data aligns with the importance of technology and how technology impacts policing today and in the near future [14]. The data analysis also divulges students' lack of knowledge, skill, and experience with certain technologies that will play a role in policing. The lack of knowledge, skill, and experience with these technologies validate two issues that future technology officers and law enforcement agencies will encounter; future officers are not being educated and trained on how to effectively use certain technologies that will play a key role in policing and law enforcement agencies will need to recruit college educated officers that have the skills, knowledge, and experience with current and future police technologies. 


\section{CONCLUSIONS AND RECOMMENDATIONS}

This paper has highlighted the rapid adoption of new technologies by police agencies and the lack of targeted police recruiting for police agencies to meet the needs for these technologies. According to a 2015 NIJ report [16] police departments need to start recruiting for future technology officers. There is little evidence to suggest that police agencies are recruiting specifically for technology skills, nor is there evidence that the same effort is being placed on technologically skilled officers as compared to the emphasis and effort in minority and women recruitment. While the authors are not recommending a change in recruitment strategy as far as minorities and women are concerned, rather a coordinated effort to recruit technology officers should be included in these programs as to cast the widest net. In addition, recruitment of officers in IT and CIS programs should be considered, until CJ programs mature to meet police agency needs.

That same NIJ report outlined that technical training and education will have to change for future police officers. As such, this paper also revealed that colleges and universities that offer criminal justice programs are not adequately training new officers to meet future technological needs. Upon analyzing 28 criminal justice (CJ) programs in Pennsylvania and four well- known national programs, only one CJ program offered the most well rounded curriculum incorporating a theoretical, vocational and technical multidiscipline approach as recommended in the literature. While this singular program does not meet all the future needs recommended by the National Institute of Justice, it covers a wide swath of them. Future CJ programs should start to examine externally and cross-pollinate with IT and CIS programs that already exist at many schools, to create forward leaning CJ programs that address the need for future technology officers. The synthesis of these programs will allow for more prepared police recruits, while equipping student participants with additional skills that can be utilized in both public and private sectors.

Finally, the researchers considered the current perceptions of criminal justice students on the importance and impact of technology in law enforcement today and in the near future. The data demonstrated how criminal justice students' perceptions allude to the importance and relevancy of technology in law enforcement and how CJ programs may not be adequately preparing them for future policing needs. Criminal Justice students recognize the impact that technology is having on policing, even though many of the higher education institutions they attend do not. While many students believe they have some of the technological skills needed, they also realize that they lack many of the necessary high-tech skills that many police agencies will need.

\section{REFERENCES}

1. Alcindor, Y., \& Penzenstadler, N. (2015). Police redouble efforts to recruit diverse officers. Retrieved from http://www.usatoday.com/story/news/2015/01/21/police-redoubling-efforts-to-recruit-diverseofficers/21574081

2. Birzer, M. L., \& Palmiotto, M. J. (2002). Criminal justice education: Where have we been? And where are we heading?. The Justice Professional, 15(3), 203-211

3. Creswell, J. (2013). Qualitative Inquiry \& Research Design: Choosing Among Five Approaches. Thousands Oaks, CA: Sage Publications.

4. Flanagan, T. J. (2000). Liberal education and the criminal justice major. Journal of Criminal Justice Education, 11(1), 1-13.

5. Goodison, S. E., Davis, R. C., \& Jackson, B. A. (2015). Digital Evidence and the US Criminal Justice System. RAND

6. Growette Bostaph, L., Brady, P., \& Giacomazzi, A. (2014). Criminal Justice Education: Are We Missing Onethird of the Crime Triangle?. Journal of Criminal Justice Education, 25(4), 468-485.

7. Hartle III, F., Parker, M., \& Wydra, C. (2014). The digital case file: The future of fighting crime with big data. Issues in Information Systems, 15(1).

8. Joh, E. E. (2014). Policing by Numbers: Big Data and the Fourth Amendment.

9. Levin, A., Goodrick, P., \& Ilkina, D. (2012). Securing cyberspace: a comparative review of strategies worldwide. The Privacy and Cyber Crime Institute.

10. McFall, E. (2006). Changing Profession Requires New Level of Education. The Police Chief, vol. 73, no. 8.

11. Nardi, P. (2006). Doing Survey Research: A Guide to Quantitative Methods. Boston, MA: Person Education.

12. Reaves, B. A. (2012). Hiring and Retention of State and Local Law Enforcement Officers, 2008-Statistical Tables. Bureau of Justice Statistics, Washington, DC. 


\section{Issues in Information Systems}

Volume 16, Issue IV, pp. 224-231, 2015

13. Rydberg, J., \& Terrill, W. (2010). The effect of higher education on police behavior. Police Quarterly, 13(1), $92-1$.

14. Schanz, Y. Y. (2013). Perceptions of Undergraduate Students on Criminology and Criminal Justice Education in the United States: An Empirical Analysis.International Journal of Criminal Justice Sciences, 8(2).

15. Sherman, L. W. (2015). A Tipping Point for "Totally Evidenced Policing" Ten Ideas for Building an EvidenceBased Police Agency. International Criminal Justice Review, 1057567715574372.

16. Silberglitt, R., Chow, B. G., Hollywood, J. S., Woods, D., Zaydman, M., \& Jackson, B. A. (2015). Visions of Law Enforcement Technology in the Period 2024-2034. NIJ

17. Soy, S. (1997). A Case Study Research Method. Retrieved from: https://www.ischool.utexas.edu/ssoy/usesusers/1391d1b.htm

18. Verrill, S. W. (2007). Criminal Justice Education and Vocationally-Oriented Students: An Examination of Agency College Degree Requirements. Southwest Journal of Criminal Justice, 4(1).

19. Wadman, R. C., \& Allison, W. T. (2004). To protect and to serve: a history of police in America. Upper Saddle River, N.J.: Prentice Hall.

20. Yin, R. (2014). Case Study Research: Designs and Methods $5^{\text {th }}$ Ed. Los Angels, CA: Sage Publications Inc. 